\title{
Polyomavirus nephropathy after kidney transplantation
}

\author{
Benjamin Seront, Selda Aydin, Martine De Meyer, Nada Kanaan
}

Cliniques Universitaires Saint-Luc, Bruxelles, Belgium

\section{Correspondence to} Professor Nada Kanaan, nada.kanaan@uclouvain.be

Accepted 2 December 2016

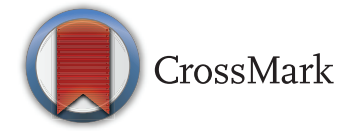

To cite: Seront $B$, Aydin $S$, De Meyer $\mathrm{M}$, et al. BMJ Case Rep Published online: [please include Day Month Year] doi:10.1136/bcr-2016217465

\section{DESCRIPTION}

A 68-year-old woman was transplanted pre-emptively with a kidney from a deceased donor in May 2012. Her immunosuppressive treatment included thymoglobulin, and tacrolimus, mycophenolate mofetyl (MMF), methylprednisolone. Ten months later, a positive urinalysis for decoy cells (figure 1) preceded a rise in creatinine to $2 \mathrm{mg} / \mathrm{dL}$. Blood PCR for BK DNA detected 45915 copies/mL. Kidney biopsy disclosed BK virus nephropathy (BKVN; figure 2). MMF was withdrawn and tacrolimus decreased to $4 \mathrm{ng} / \mathrm{mL}$ trough level. Three months later, the virus was undetectable. Creatinine remained stable over the following years $(2 \mathrm{mg} / \mathrm{dL})$. Donor-specific antiHLA antibodies remained negative.

BKVN has emerged as a cause of graft loss. BK virus is a polyomavirus prevalent in $60-80 \%$ of the general population. It colonises mainly the renourinary tract where it remains latent. The intensity of immunosuppression is the main risk factor for BKVN. BK virus appears first in the urine, then in the blood, and ultimately progresses to the graft. ${ }^{1}$ Antiviral therapies are lacking. Thus, screening is essential, and recommended during the first posttransplant year. A kidney graft biopsy should be performed when plasma BKV DNA loads is $>4 \log 10$ copies $/ \mathrm{mL}^{2}$ Since BKVN can be focal in distribution, negative results cannot rule out the diagnosis. The primary treatment is reducing the intensity of immunosuppression, by discontinuing the antimetabolite and reducing calcineurin inhibitor trough level. ${ }^{3}$ Graft failure occurs in $30-60 \%$ of patients, but outcomes have improved since screening has permitted prompt decrease of immunosuppression.
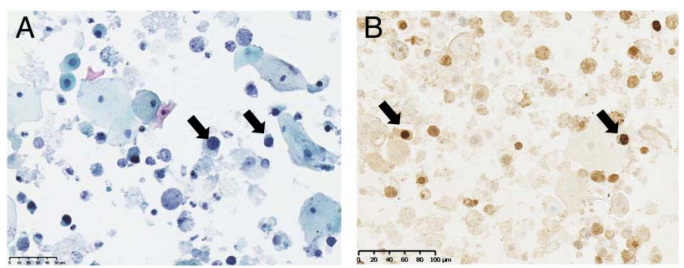

Figure 1 Urine cytology shows decoy cells corresponding to tubular epithelial cells infected with BK virus and shed in the urine. (A) Some epithelial cells have enlarged nuclei with ground glass appearance (arrows). (B) Immunohistochemistry staining using antibody against simian virus 40 large $\mathrm{T}$ antigen revealing infected cells.

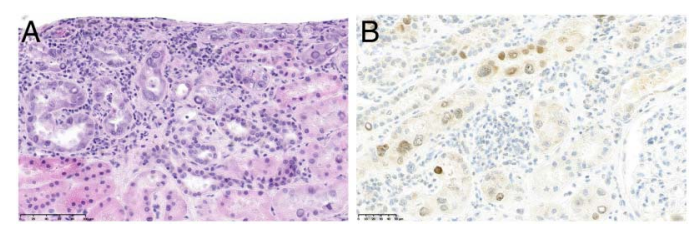

Figure 2 Kidney graft biopsy showing BKVN. (A) H\&E stain shows interstitial inflammation located around infected tubules. Infected tubular cells have enlarged nuclei with intranuclear viral inclusion. (B) Immunohistochemical staining for SV40-T antigen showing positively stained nuclei in tubular epithelial cells. BKVN, BK virus nephropathy.

Retransplantation is possible in virologically quiescent patients, but requires close monitoring of $\mathrm{BK}$ viremia. $^{2}$

\section{Learning points}

Polyomavirus nephropathy is a cause of kidney graft dysfunction and graft failure.

- The intensity of immunosuppression is the main risk factor.

- Reduction of immunosuppression is the primary treatment.

- Screening allows early diagnosis and better outcomes.

Contributors BS and NK took care of the patient and wrote the manuscript. MDM performed the biopsy. SA interpreted and provided the images.

Competing interests None declared.

Patient consent Obtained.

Provenance and peer review Not commissioned; externally peer reviewed.

\section{REFERENCES}

1 Randhawa P, Brennan DC. BK virus infection in transplant recipients: an overview and update. Am J Transplant 2006:6:2000-5.

2 Hirsch $\mathrm{HH}$, Vincenti $\mathrm{F}$, Friman $\mathrm{S}$, et al. Polyomavirus BK replication in de novo kidney transplant patients receiving tacrolimus or cyclosporine: a prospective, randomized, multicenter study. Am J Transplant 2013;13:136-45.

3 Dall A, Hariharan S. BK virus nephritis after renal transplantation. Clin J Am Soc Nephrol 2008;3(Suppl 2):S68-75. 
Copyright 2016 BMJ Publishing Group. All rights reserved. For permission to reuse any of this content visit http://group.bmj.com/group/rights-licensing/permissions.

BMJ Case Report Fellows may re-use this article for personal use and teaching without any further permission.

Become a Fellow of BMJ Case Reports today and you can:

- Submit as many cases as you like

- Enjoy fast sympathetic peer review and rapid publication of accepted articles

- Access all the published articles

Re-use any of the published material for personal use and teaching without further permission

For information on Institutional Fellowships contact consortiasales@bmjgroup.com

Visit casereports.bmj.com for more articles like this and to become a Fellow 